\title{
Peningkatan Sensitivitas Kaki Pada Pasien Diabetes Melitus Yang Mengalami Neuropati Diabetikum Melalui Latihan Senam Ergonomik
}

\author{
Maria Karolina Selano ${ }^{1}$, Suhadi ${ }^{2}$, Maria Theresia Priyastuti ${ }^{3}$ \\ 1,2,3 Keperawatan, Sekolah Tinggi Ilmu Kesehatan Elisabeth Semarang \\ email : ${ }^{1}$ mariaselano100284@gmail.com, ${ }^{2}$ priyastutimariastibeth@gmail.com, \\ ${ }^{3}$ suhadi9264@yahoo.com
}

\begin{abstract}
ABSTRAK
Latar belakang :Diabetes melitus adalah penyakit kronis yang terjadi karena pankreas tidak menghasilkan cukup insulin atau ketika tubuh tidak dapat secara efektif menggunakan insulin yang dihasilkannya. Jika dibandingkan dengan tahun 2013, prevalensi DM berdasarkan diagnosis dokter pada penduduk umum $\geq$ 15 tahun hasil Riskesdas 2018 meningkat menjadi $2 \%$. Hiperglikemia dapat berdampak buruk pada berbagai macam organ tubuh seperti neuropati diabetik, ulkus kaki, retinopati diabetik, nefropati diabetik dan gangguan pembuluh darah. Senam ergonomik adalah salah satu dari berbagai macam aktivitas fisik yang paling efektif diberikan kepada penderita diabetes dengan keluhan kurangnya tingkat sensitivitas kaki karena aktivitas senam ergonomik mempunyai manfaat meningkatkan sensitivitas kaki, memperlancar sirkulasi darah, memperkuat otot otot kecil, mengatasi keterbatasan gerak sendi, mencegah terjadinya kelainan kaki dan meningkatkan kebugaran.
\end{abstract}

Tujuan : Tujuan dari pemberian senam ergonomik ini adalah untuk meningkatkan sensitivitas kaki pasien diabetes melitus yang mengalami neuropati diabetikum sebanyak 20 pasien pada tanggal 06 Juli - 19 Juli 2019.

Metode : Prosedur pelaksanaan yaitu pertama menjelaskan kepada pasien mengenai tujuan dalam pemberian latihan fisik senam ergonomik yaitu untuk meningkatkan sensitivitas kaki pada penderita neuropati diabetikum, menjelaskan cara kerja, melakukan pemeriksaan sensitivitas kaki dengan menggunakan monofilament test sebelum dilakukan senam ergonomik, melakukan senam ergonomik 1 kali sehari selama 14 hari dan pada hari terakhir melakukan test sensitivitas kaki dengan menggunakan monofilament test.

Hasil yang diperoleh yaitu terdapat peningkatan sensitifitas kaki pada pasien diabetes mellitus yang mengalami neuropati diabetikum dengan hasil rata - rata peningkatan sensitivitas kaki kiri setelah dilakukan senam ergonomik 1 kali sehari selama 14 hari sebesar 8,55 dan rata - rata peningkatan sensitivitas kaki kanan setelah dilakukan senam ergonomik 1 kali sehari selama 14 hari sebesar 8,5 .

KATA KUNCI: Sensitivitas kaki, Senam ergonomik; Diabetes mellitus; Neuropati diabetikum

\section{ABSTRACT}

Background : Diabetes is a chronic disease that occurs because the pancreas does not produce enough insulin or when the body cannot effectively use the insulin produced. When compared with it in 2013, the prevalence of DM based on doctor's diagnosis in the general population $\geq 15$ years of the result from 2018 Riskesdas increased to 2\%. Hyperglycemia can adversely affect on various 
organs of the body such as diabetic neuropathy, foot ulcers, diabetic retinopathy, diabetic nephropathy and blood vessel disorders. Ergonomic gymnastics is one of the most effective types of physical activity given to diabetics with complaints of a lack of foot sensitivity because activities of ergonomic gymnastics have the benefit of increasing foot sensitivity, improving blood circulation, strengthening small muscles, overcoming limitations of joint motion, preventing the occurrence of joint pain, foot deformities and improving fitness.

Objective: The purpose of giving the ergonomic gymnastics is to increase the foot sensitivity of diabetes mellitus patients who experience diabetic neuropathy as many as 20 patients on 06 July - 19 July 2019.

Methods: The implementation procedure is first to explain the patient about the purpose of giving physical exercise of ergonomic gymnastics, namely to increase the foot sensitivity in diabetic neuropathy patients, to explain how it works, to check the foot sensitivity using a monofilament test before doing ergonomic gymnastics, to do ergonomic gymnastics once a day. for 14 days and on the last day to do the foot sensitivity test using a monofilament test.

The results obtained are that there is an increase of the foot sensitivity on diabetes mellitus patients who experience diabetic neuropathy with an average increase in the left foot sensitivity after doing ergonomic gymnastics once a day for 14 days is 8.55 and an average increase in the right foot sensitivity after doing ergonomic gymnastics once a day for 14 days is 8.5 .

KEYWORDS: Foot sensitivity, Ergonomic gymnastics; Diabetes mellitus; Diabetic neuropathy

\section{Pendahuluan}

International Diabetes Federation (IDF) Atlas 2017 melaporkan bahwa epidemi Diabetes di Indonesia masih menunjukkan kecenderungan meningkat. Indonesia adalah negara dengan peringkat keenam di dunia setelah Tiongkok, India, Amerika Serikat, Brazil dan Meksiko dengan jumlah penyandang Diabetes usia 20 - 79 tahun sekitar 10,3 juta orang. Diabetes adalah penyakit kronis yang terjadi karena pankreas tidak menghasilkan cukup insulin atau ketika tubuh tidak dapat secara efektif menggunakan insulin yang dihasilkannya. Jika dibandingkan dengan tahun 2013, prevalensi DM berdasarkan diagnosis dokter pada penduduk umum $\geq 15$ tahun hasil Riskesdas 2018 meningkat menjadi $2 \%$. Seiring dengan bertambahnya jumlah penderita diabetes, maka penderita diabetes harus melakukan pengaturan diri terhadap penyakit dalam bentuk perawatan diri agar kadar glokosa berada pada level normal ${ }^{1}$.

Hiperglikemia yang terjadi dari waktu ke waktu dapat menyebabkan kerusakan berbagai sistem tubuh terutama syaraf dan pembuluh darah. Beberapa konsekuensi dari diabetes yang sering terjadi adalah : Meningkatnya resiko penyakit jantung dan stroke, Neuropati (kerusakan syaraf) di kaki yang meningkatkan kejadian ulkus kaki, infeksi dan bahkan keharusan untuk amputasi kaki. Retinopati diabetikum yang merupakan salah satu penyebab utama kebutaan, terjadi akibat kerusakan pembuluh darah kecil di retina, diabetes merupakan salah satu penyebab utama gagal ginjal, risiko kematian penderita diabetes secara umum adalah dua kali lipat dibandingkan bukan penderita diabetes ${ }^{2}$.

Dengan pengendalian metabolisme yang baik, menjaga kadar gula darah berada dalam kategori normal, maka komplikasi akibat diabetes dapat 
dicegah/ditunda. Data persentase komplikasi diabetes melitus di RSUP Dr. Cipto Mangunkusumo Jakarta (RSCM) tahun 2011 komplikasi terbanyak adalah neuropati yang dialami oleh $54 \%$ penderita diabetes melitus yang dirawat di RSCM pada tahun 2011 diikuti retinopati diabetik dan poteinuria. Komplikasi menahun DM di Indonesia terdiri atas neuropati $60 \%$, penyakit jantung koroner $20,5 \%$, Kaki diabetik $15 \%$, retinopati $10 \%$, dan nefropati $7,1 \%$. Penatalaksanaan diabetes melitus yang tidak tepat menyebabkan glukosa darah pasien menjadi sulit terkontrol dan dapat mengakibatkan berbagai komplikasi seperti neuropati diabetik, nefropati diabetic, stroke, kebutaan dan ulkus diabetic yang akan mempengaruhi kualitas hidup pasien diabetes melitus ${ }^{3}$.

Neuropati diabetik merupakan komplikasi tersering dari penyakit diabetik. Proses terjadinya kaki diabetic diawali oleh angiopati, neuropati dan infeksi. Neuropati menyebabkan gangguan sensorik yang menghilangkan atau menurunkan sensasi nyeri kaki sehingga ulkus dapat terjadi tanpa terasa. Gangguan motorik menyebabkan atrofi otot tungkai sehingga mengubah titik tumpu yang menyebabkan ulserasi kaki. Infeksi sering merupakan komplikasi akibat berkurangnya aliran darah atau neuropati. Ulkus diabetic bisa menjadi ganggren kaki diabetic ${ }^{4}$.

Peningkatan prevalensi DM dan komplikasi menunjukkan pentingnya upaya pencegahan. Pencegahan DM adalah dengan mengupayakan kadar glukosa darah dalam tubuh menjadi normal. Upaya untuk menurunkan kadar gula darah yaitu melalui empat pilar penatalaksanaan DM seperti edukasi, perencanaan makan, latihan jasmani dan terapi farmakologi ${ }^{5}$.

Pada saat ini, banyak penderita diabetes melitus yang lebih fokus pada penanganan diet dan mengkonsumsi obat - obatan, padahal penanganan diet yang teratur belum menjamin akan kestabilan kadar glukosa darah, akan tetapi hal ini harus dilakukan dengan latihan fisik yang sesuai ${ }^{6}$. Sebab jika penderita diabetes tidak melakukan aktifitas fisik maka metabolisme otot yang terjadi hanya sedikit, sehingga pemakaian glukosa dalam darah berkurang. Hal ini menyebabkan penumpukan glukosa dalam darah, sehingga glukosa dalam darah tinggi. Pengelolaan diabetes melitus meliputi 5 pilar yaitu perencanaan diet, latihan jasmani, terapi farmakologis, edukasi dan pemantauan kadar glukosa darah. Latihan fisik merupakan cara yang sangat penting untuk dilakukan oleh penderita diabetes melitus terutama dalam menangani peningkatan glukosa dalam darah. Latihan fisik seperti senam ergonomik akan menurunkan kadar glukosa darah dengan meningkatkan pengambilan glukosa oleh otot dan memperbaiki pemakaian insulin serta memperlancar sirkulasi darah ${ }^{7}$.

Senam ergonomik adalah salah satu dari berbagai macam aktivitas fisik yang paling efektif diberikan kepada penderita diabetes dengan keluhan kurangnya tingkat sensitivitas kaki, dari penelitian yang dilakukan oleh Tri Susilowati dan Fitri Windawati (2016) yang berjudul "Senam Ergonomik Meningkatkan Sensitivitas Kaki Pada Penderita Diabetes Mellitus di Kelurahan Purwosari Kecamatan Laweyan Kota Surakarta" menunjukkan hasil dari penelitian tersebut senam ergonomik dapat mengurangi keluhan kurangnya tingkat sensitivitas kaki pada penderita diabetes mellitus, karena aktivitas senam ergonomik mempunyai manfaat meningkatkan sensitivitas kaki, memperlancar sirkulasi darah, memperkuat otot - otot kecil, mengatasi keterbatasan gerak sendi, mencegah terjadinya kelainan kaki dan meningkatkan kebugaran ${ }^{8}$.

Senam ergonomik adalah senam fundamental yang gerakannya sesuai dengan susunan dan fungsi fisiologis tubuh. Tubuh dengan sendirinya terpelihara homeostatisnya (keteraturan dan keseimbangannya) sehingga tetap dalam keadaan bugar. Inti gerakan dari senam ergonomik adalah untuk membuang energi negatif 
dan dapat membakar asam urat, kolesterol dan gula darah. Manfaat dari senam ergonomik ini adalah untuk memperbaiki posisi tubuh, meningkatkan metabolisme, memperbaiki sirkulasi darah, memperkuat otot - otot kecil dan mengoptimalkan suplai darah dan oksigen ke otak. Keadaan hiperglikemia yang terjadi baik secara kronis memberikan dampak buruk terhadap jaringan yang secara jangka panjang menimbulkan komplikasi kronis dari diabetes. Tingginya kadar glukosa darah (glukotoxicity) yang diikuti pula oleh dislipidemia (lipotoxicity) bertanggung jawab terhadap kerusakan jaringan ${ }^{9}$.

Dengan latihan fisik, dapat meningkatkan tingkat sensitivitas insulin terhadap jaringan dan resistensi insulin berkurang. Latihan fisik dapat meningkatkan hemodinamik, dan meningkatkan kebutuhan protein seluler, yang akan meningkatkan aliran darah. Peningkatan aliran darah ini merangsang insulin receptor substrate pada membran sel yang berguna bagi proses metabolisme glukosa di dalam sel otot atau lemak, kemudian glukosa dapat berpindah ke dalam sel sehingga terjadi penurunan kadar glukosa dalam darah. Dengan adanya peningkatan aliran darah ini, merangsang serabut syaraf perifer untuk menerima stimulus sehingga terjadi peningkatan sensitivitas kaki ${ }^{10}$.

\section{Metode}

2.1. Waktu dan Tempat

Pemberian senam ergonomik ini dilakukan kepada pasien diabetes mellitus yang mengalami gangguan sensitivitas kaki sebanyak 20 pasien pada tanggal 06 Juli - 19 Juli 2019 di wilayah Kelurahan Tembalang Semarang.

\subsection{Bahan dan Alat}

Bahan dan alat yang digunakan terdiri dari alat pemeriksaan sensitivitas kaki yaitu monofilament test, lembar catatan hasil pemeriksaan dan bolpoint.

\subsection{Cara Pemeriksaan}

Prosedur pelaksanaan yaitu pertama menjelaskan kepada pasien mengenai tujuan dalam pemberian latihan fisik senam ergonomik yaitu untuk meningkatkan sensitivitas kaki pada penderita neuropati diabetikum. Langkah selanjutnya melakukan penandatanganan informed consent jika pasien sudah bersedia dan menyetujui untuk dilakukan latihan fisik senam ergonomik 1 kali sehari selama 14 hari, kemudian melakukan kesepakatan waktu dan tempat untuk melakukan latihan fisik senam ergonomik. Sebelum dan setelah dilakukan senam ergonomik, semua pasien akan dilakukan pemeriksaan atau test sensitivitas kaki dengan menggunakan monofilament test.

\section{Hasil dan Pembahasan}

3.1. Mekanisme pelaksanaan kegiatan latihan senam ergonomik yaitu sebagai berikut :

3.1.1. Perencanaan

Kegiatan yang dilakukan dalam tahap perencanaan adalah :

1) Tim pengabdian kepada masyarakat mengadakan pertemuan dengan LPPM

2) Penyusunan kegiatan latihan senam ergonomil

Berdasarkan hasil indentifikasi permasalah dan hasil analisis kebutuhan di masyarakat, selanjutnya dilakukan kegiatan latihan senam ergonomic 


\subsubsection{Tindakan}

Tindakan dalam kegiatan ini yaitu melaksanakan pemeriksaan sensitivitas kaki dan senam ergonomic. Senam ergonomik untuk meningkatkan sensitivitas kaki pada pasien dengan neuropati diabetikum di daerah wilayah Kelurahan Tembalang Semarang, dilakukan 1 kali sehari selama 14 hari dimulai tanggal 06 Juli 2019 sampai 19 Juli 2019. Pengambilan data dilakukan dengan cara menjelaskan prosedur dan memberikan inform consent pada setiap pasien. Melakukan pemeriksaan monofilament test untuk menentukan tingkat sensitivitas kaki pasien, lalu sebelum diberi perlakuan senam ergonomik, pasien diajarkan langkah - langkah senam. Setelah itu pasien diberi perlakuan senam ergonomik 1 kali sehari selama 14 hari. Kemudian melakukan evaluasi adanya perubahan tingkat sensitivitas kaki dengan pemeriksaan monofilament.

\subsubsection{Evaluasi}

Evaluasi dilakukan dengan melakukan monitoring pelaksanaan kegiatan pemeriksaan sensitivitas kaki dan latihan senam ergonomik

\subsection{Hasil}

3.2.1. Karakteristik pasien berdasarkan umur

Tabel. 1. Karakteristik pasien berdasarkan umur

\begin{tabular}{ccc}
\hline Usia & Frekuensi & $\%$ \\
\hline$(36-45$ tahun $)$ & 4 & $20 \%$ \\
$(46-55$ tahun $)$ & 3 & $15 \%$ \\
$(56-65$ tahun $)$ & 8 & $40 \%$ \\
$(65$ tahun ke atas $)$ & 5 & $25 \%$ \\
\hline Total & 20 & $100 \%$
\end{tabular}

Dari tabel 1 dapat diketahui bahwa pasien yang bersedia menjadi responden dalam implementasi pemberian senam ergonomik ini sebagian besar adalah lansia akhir yang berusia (56 -65 tahun) sebanyak 8 (40\%).

\subsubsection{Karakteristik pasien berdasarkan jenis kelamin}

Tabel 2. Karakterisktik pasien berdasarkan jenis kelamin

\begin{tabular}{ccc}
\hline Jenis kelamin & Frekuensi & $\%$ \\
\hline Laki - laki & 6 & $30 \%$ \\
Perempuan & 14 & $70 \%$ \\
\hline Total & 20 & 100 \\
\hline
\end{tabular}

Dari tabel 2. diatas menunjukkan bahwa pasien sebagian besar berjenis kelamin perempuan sebanyak 14 orang $(70 \%)$. 
3.2.3. Karakteristik pasien berdasarkan kadar gula darah sebelum dan sesudah dilakukan perlakuan senam ergonomic

Tabel 3. Kadar gula sebelum dan sesudah dilakukan senam ergonomic

\begin{tabular}{|c|c|c|c|}
\hline Pasien & $\begin{array}{c}\text { Kadar gula darah sebelum } \\
(\mathrm{mg} / \mathrm{dl})\end{array}$ & $\begin{array}{c}\text { Kadar gula darah } \\
\text { sesudah }(\mathrm{mg} / \mathrm{dl})\end{array}$ & Selisih \\
\hline $\mathrm{P} 1$ & 292 & 166 & 126 \\
\hline P2 & 360 & 228 & 132 \\
\hline P3 & 339 & 129 & 210 \\
\hline P4 & 268 & 220 & 48 \\
\hline P5 & 402 & 390 & 12 \\
\hline P6 & 346 & 312 & 34 \\
\hline P7 & 480 & 418 & 62 \\
\hline P8 & 299 & 180 & 119 \\
\hline P9 & 429 & 210 & 219 \\
\hline P10 & 348 & 198 & 150 \\
\hline P11 & 356 & 210 & 146 \\
\hline P12 & 424 & 236 & 188 \\
\hline P13 & 368 & 305 & 63 \\
\hline P14 & 320 & 180 & 140 \\
\hline P15 & 305 & 198 & 107 \\
\hline P16 & 428 & 218 & 210 \\
\hline P17 & 468 & 270 & 198 \\
\hline P18 & 358 & 187 & 171 \\
\hline P19 & 386 & 228 & 158 \\
\hline P20 & 428 & 220 & 208 \\
\hline Rata-rata & 370,2 & 235,15 & 135,05 \\
\hline
\end{tabular}

3.2.4. Karakteristik pasien berdasarkan tingkat sensitivitas kaki kiri sebelum dan sesudah dilakukan senam ergonomik

Tabel 4. Tingkat sensitivitas kaki kiri sebelum dan sesudah dilakukan senam ergonomic

\begin{tabular}{cccc}
\hline Pasien & Sebelum & Sesudah & Selisih \\
\hline P1 & $8 / 10$ & $10 / 10$ & 2 \\
P2 & $8 / 10$ & $9 / 10$ & 1 \\
P3 & $8 / 10$ & $10 / 10$ & 2 \\
\hline
\end{tabular}




\begin{tabular}{|c|c|c|c|}
\hline $\mathrm{P} 4$ & $7 / 10$ & $8 / 10$ & 1 \\
\hline P5 & $7 / 10$ & $7 / 10$ & 0 \\
\hline P6 & $7 / 10$ & $7 / 10$ & 0 \\
\hline $\mathrm{P} 7$ & $6 / 10$ & $6 / 10$ & 0 \\
\hline P8 & $7 / 10$ & $8 / 10$ & 1 \\
\hline P9 & $6 / 10$ & $8 / 10$ & 2 \\
\hline $\mathrm{P} 10$ & $8 / 10$ & $9 / 10$ & 1 \\
\hline P11 & $8 / 10$ & $9 / 10$ & 1 \\
\hline P12 & $9 / 10$ & $10 / 10$ & 1 \\
\hline P13 & $7 / 10$ & $8 / 10$ & 1 \\
\hline P14 & $6 / 10$ & $8 / 10$ & 2 \\
\hline $\mathrm{P} 15$ & $8 / 10$ & $9 / 10$ & 1 \\
\hline P16 & $8 / 10$ & $10 / 10$ & 2 \\
\hline P17 & $6 / 10$ & $8 / 10$ & 2 \\
\hline P18 & $7 / 10$ & $9 / 10$ & 2 \\
\hline P19 & $7 / 10$ & $9 / 10$ & 2 \\
\hline P20 & $8 / 10$ & $9 / 10$ & 1 \\
\hline Rata - rata & 7,3 & 8,55 & 1,25 \\
\hline
\end{tabular}

3.2.5. Karakterisktik pasien berdasarkan tingkat sensitivitas kaki kanan sebelum dan sesudah dilakukan senam ergonomik.

Tabel 5. Tingkat sensitivitas kaki kanan sebelum dan sesudah dilakukan senam ergonomik

\begin{tabular}{cccc}
\hline Pasien & Sebelum & Sesudah & Selisih \\
\hline P1 & $8 / 10$ & $10 / 10$ & 2 \\
P2 & $8 / 10$ & $9 / 10$ & 1 \\
P3 & $8 / 10$ & $10 / 10$ & 2 \\
P4 & $8 / 10$ & $8 / 10$ & 0 \\
P5 & $7 / 10$ & $8 / 10$ & 1 \\
P6 & $7 / 10$ & $7 / 10$ & 0 \\
P7 & $6 / 10$ & $6 / 10$ & 0 \\
P8 & $7 / 10$ & $7 / 10$ & 0 \\
P9 & $8 / 10$ & $9 / 10$ & 1 \\
P10 & $8 / 10$ & $9 / 10$ & 1 \\
P11 & $7 / 10$ & $8 / 10$ & 1 \\
\hline
\end{tabular}




\begin{tabular}{llll}
\hline P12 & $6 / 10$ & $8 / 10$ & 2 \\
P13 & $7 / 10$ & $9 / 10$ & 2 \\
P14 & $8 / 10$ & $9 / 10$ & 1 \\
P15 & $8 / 10$ & $9 / 10$ & 1 \\
P16 & $6 / 10$ & $8 / 10$ & 2 \\
P17 & $8 / 10$ & $9 / 10$ & 1 \\
P18 & $7 / 10$ & $9 / 10$ & 2 \\
P19 & $8 / 10$ & $9 / 10$ & 1 \\
P20 & $8 / 10$ & $9 / 10$ & 1 \\
\hline Rata - rata & 7,4 & 8,5 & 1,1 \\
\hline
\end{tabular}

\subsection{Pembahasan}

Diabetes Melitus (DM) didefinisikan sebagai kumpulan gejala pada seseorang akibat tubuh mengalami gangguan atau tidak dapat mengontrol kadar gula darah. Masalah tersebut dapat disebabkan oleh sekresi hormone insulin yang tidak adekuat atau fungsi insulin terganggu ( resistensi pada kadar insulin) atau dapat juga berupa gangguan pada keduanya atau gabungan dari kedua kondisi tersebut atau gangguan metabolisme menahun akibat pankreas tidak memproduksi ${ }^{11}$.

Pasien diabetes melitus yang dalam kehidupan sehari - hari tidak dikelola dengan baik atau pola hidup yang tidak sehat akan meningkatkan resiko terjadinya komplikasi. Komplikasi ini dapat disebabkan karena terjadinya defisiensi insulin atau dapat juga disebabkan karena kerja insulin yang tidak adekuat. Untuk komplikasi yang muncul ini dapat bersifat akut maupun kronik. Yang termasuk dalam komplikasi akut ini terjadi berkaitan dengan peningkatan kadar gula darah secara tiba - tiba, sedangkan komplikasi kronik dapat terjadi akibat peningkatan kadar gula dalam darah yang berlangsung dalam waktu yang lama ${ }^{12}$.

Neuropati diabetikum termasuk dalam kelompok gangguan saraf yang disebabkan oleh diabetes melitus. Pasien diabetes melitus dari waktu ke waktu dapat berkembang menjadi kerusakan saraf di seluruh tubuh. Beberapa pasien dengan kerusakan saraf tidak memiliki gejala dan mungkin beberapa lainnya mengalami gejala seperti nyeri dan hilangnya rasa pada ekstermitas. Sekitar $60 \%$ sampai $70 \%$ pasien dengan diabetes melitus dapat mengalami neuropati. Deteksi dini neuropati sangat penting pada pasien diabetes melitus, karena intervensi pencegahan dapat diterapkan untuk menurunkan angka kesakitan ${ }^{13}$. Neuropati berkembang akibat akumulasi produk glukosa yang menghasilkan peningkatan aktivasi enzim aldose reduktase dan sorbitol dehidrogenase. Hal ini menyebabkan konversi glukosa menjadi sorbitol dan fruktosa. Selain itu terjadi peningkatan vasokonstriktor yang berakibat pada iskemia sel saraf. Perkembangan ulkus diabetik pada pasien diabetes melitus didahului oleh riwayat trauma. Neuropati menyebabkan hilangnya sensasi pada kaki yang mengakibatkan trauma yang tidak dapat dirasakan terutama pada daerah yang mendapatkan tekanan berulang. Hal ini mengakibatkan banyak luka trauma yang tidak disadari oleh pasien dan semakin memperburuk perkembangan ulserasi ${ }^{13}$.

Aktivitas senam ergonomik dapat meningkatkan aliran darah, sehingga aliran darah ke jaringan perifer menjadi adekuat dan karena adanya peningkatan sirkulasi darah ini maka merangsang serabut syaraf perifer untuk menerima stimulis sehingga terjadi peningkatan sensitivitas kaki. Senam ergonomik secara rutin dan teratur dapat 
meningkatkan tingkat sensitivitas kaki pada penderita neuropati diabetikum. Selain mudah dilakukan senam ini juga dapat membantu meningkatkan aliran darah sehingga dapat merangsang insulin receptor substrate pada membran sel yang berguna bagi proses metabolisme glukosa di dalam sel otot atau lemak untuk dibentuk menjadi energi dalam melakukan aktivitas fisik ${ }^{14}$. Latihan fisik dinamik yang melibatkan otot otot utama akan menyebabkan permeabilitas meningkat pada otot yang berkontraksi, sehingga saat latihan reseptor insulin akan banyak dan lebih peka. Senam ergonomik merupakan kombinasi dari Gerakan otot dan pernapasan. Senam ergonomic dapat menurunkan kadar gula darah karena saat melakukan senam ergonomic otot - otot digerakan secara optimal sehingga lebih banyak menyerap gula untuk proses pembakaran. Latihan fisik akan menurunkan kadar glukosa darah dengan meningkatkan pengambilan glukosa oleh otot dan memperbaiki pemakaian insulin serta memperlancar sirkulasi darah ${ }^{14}$.

\section{Kesimpulan}

1. Senam ergonomik memiliki pengaruh untuk penurunan kadar gula darah pada pasien yang menderita penyakit diabetes dengan neuropati diabetikum

2. Hasil rata - rata tingkat sensitivitas kaki kiri sebelum dilakukan senam ergonomic adalah 7,3 dan rata - rata tingkat sensitivitas kaki kanan adalah 7,4

3. Hasil rata - rata peningkatan sensitivitas kaki kiri setelah dilakukan senam ergonomic 1 kali sehari selama 14 hari sebesar 8,55 dan rata - rata peningkatan sensitivitas kaki kanan setelah dilakukan senam ergonomic 1 kali sehari selama 14 hari sebesar 8,5

4. Selisih rata - rata peningkatan sensitivitas kaki kiri sebelum dan sesudah dilakukan senam ergonomic 1 kali sehari selama 14 hari sebesar 1,25 dan rata-rata peningkatan sensitivitas kaki kanan sebelum dan sesudah dilakukan senam ergonomic 1 kali sehari selama 14 hari sebesar 1,1.

\section{Saran}

1. Aktifitas senam ergonomik dapat digunakan sebagai terapi non farmakologi bagi pasien diabetes mellitus

2. Keberhasilan senam ergonomik untuk meningkatkan sensitivitas kaki harus didukung oleh motivasi dari diri pasien sendiri sehingga mendapatkan hasil yang maksimal.

\section{Ucapan Terimakasih}

Terimakasih kepada STIKes St. Elisabeth Semarang yang telah memberikan dukukngan moril dan materiil terhadap kegiatan Pengabdian kepada Masyarakat ini.

\section{DAFTAR PUSTAKA}

[1] Kemenkes RI, "CEGAH, CEGAH, dan CEGAH: Suara Dunia Perangi Diabetes," 2018.

https://www.kemkes.go.id/article/view/18121200001/prevent-prevent-andprevent-the-voice-of-the-world-fight-diabetes.html.

[2] F. Wolfe, K. Ross, D. J. Hawley, F. K. Roberts, and M. A. Cathey, “The prognosis of rheumatoid arthritis and undifferentiated polyarthritis syndrome in the clinic: A study of 1141 patients," J. Rheumatol., vol. 20, 
no. 12, pp. 2005-2009, 1993.

[3] R. W. Kartika, "Continuing medical education: Pengelolaan gangren kaki diabetik," CDK, vol. 44, no. 1, p. 248, 2017.

[4] A. N. Purwita, Hubungan Dukungan Keluarga Dengan Perubahan Kadar Gula Darah Pasien Diabetes Mellitus Tipe 2 Di RSUD Kota Madiun. Proposal FK Stikes Bhakti Husada Mulia Madiun, 2016.

[5] E. Sinaga, J, \& Hondro, "Pengaruh Senam Diabetes Melitus Terhadap Kadar Glukosa Darah Pada Penderita Diabetes Melitus Tipe 2 Di Wilayah Kerja Puskesmas Darusalam Medan 2011,” J. Mutiara Ners, 2012.

[6] T. Susilowati and F. Windawati, "Senam Ergonomik Meningkatkan Sensitivitas Kaki Pada Penderita Diabetes Mellitus Di Kelurahan Purwosari Kecamatan Laweyan Kota Surakarta," Matern. J. Kebidanan dan Ilmu Kesehat., vol. 3, no. 2, 2016.

[7] P. Suwondo and Subekti, Penatalaksanaan Diabetes Melitus Terpadu. Jakarta: Balai Penerbit FKUI, 2014.

[8] swr wound care program, "Procedure: Monofilament Testing for Loss of Protective Sensation of Diabetic/Neuropathic Feet (Adults and Children)," 2015. www.swrwoundcareprogram.ca.

[9] S. Anani, "Hubungan Antara Perilaku Pengendalian Diabetes dan Kadar Glukosa Darah Pasien Rawat Jalan Diabetes Melitus (Studi Kasus di RSUD Arjawinangun Kabupaten Cirebon," J. Kesehat. Masy. Univ. Diponegoro, vol. 1, no. 2, 2012.

[10] R. Chaidir, A. Wahyuni, and D. Furkhani, "Hubungan Self Care Dengan Kualitas Hidup Pasien Diabetes Melitus," J. Endur., vol. 2, no. 2, p. 132, 2017, doi: 10.22216/jen.v2i2.1357.

[11] S. Christia, A. Yuwono, and Fakhrurrazy, "Kejadian Neuropati Vaskulopati Pada Pasien Ulkus Diabetik di Poliklinik Kaki Diabetik," Berk. Kedokt., vol. 11, no. 1, pp. 25-32, 2015.

[12] W. Clayton and A. . Tom, "A Review of the Pathophysiology, Classification, and Treatment of Foot Ulcers in Diabetic Patient," Clin. Diabetes, vol. 27, no. 2, 2009.

[13] Kemenkes RI, “Infodatin Pusat Data dan Informasi Kesehatan Kementerian Kesehatan RI.” Jakarta, pp. 1-8, 2014.

[14] Perkumpulan Endokriologi Indonesia, "Pedoman Pengelolaan dan Pencegahan Diabetes Melitus Tipe 2 Dewasa di Indonesia," Jakarta: PERKENI, 2019, pp. 1-133. 